\title{
Exploring Child Leadership: \\ Preparing Leaders for Sustainable Education for the Future
}

\author{
Juzy Laygo-Saguil* \\ a jlsaguil@pwu.edu.ph \\ Philippine Women's University,Manila, Philippines
}

\begin{abstract}
Anchored on Theory on Progressive Education by John Dewey that education must prepare students for active participation in a democratic, global society, this study explores the early childhood education teachers' perceptions on child leadership. With the belief that the leaders of the future are in school today, and to better address the interconnected global challenges everyone is facing, this study also discusses the teachers' best practices on how the leadership potentials of young children could be enhanced and developed. Using qualitative research design, ten (10) teachers were purposively chosen to participate in the Focus Group discussion. The researcher used direct quotations in accordance with the nature of the data to ensure transferability. To ensure consistency, external researchers who were expert in the field were consulted for verifiability. Results show that the participants have varied views on child leadership. Enumerated child leadership characteristics were clustered under themes and classroom scenarios on how leadership skills could be enhanced were identified. Lists of suggested activities were created for teachers for them to be guided to facilitate explorations of the young learners in an engaging, creative, and child-centered programs. Since future leaders are shaped by today's training and learning, researches on the development of leadership among young children is recommended to fill the gap in the literature and to encourage building a positive teachinglearning process.
\end{abstract}

Keywords: child leadership; early childhood education; leadership skills; education for the future

\section{Introduction}

Learning must prepare students and learners of all ages to find solutions for the challenges of today and the future. This preparation for the future includes preparing future leaders. Research shows that leadership skills 
can be taught and instruction should begin in the early years. Empirical evidence suggests that it is also important that the development of leadership start early in life and should be implemented in schools.

Leadership has been called an essential component in social interaction and is an important social behavior in children. Researchers have observed leadership behavior in young children and suggested that these leadership behaviors be encouraged in early childhood classrooms. The act of teaching young children leadership skills at school builds a foundation that will serve them throughout their lives.

The purpose of this research is to explore how early childhood classroom teachers recognize leadership behavior in young children. It also focuses on identifying and enhancing the leadership competencies among young children. This study offers identification of leadership qualities that teachers want to see in their students and the applicability levels of the activities for the development of these qualities which can be regarded as significant.

This study is anchored on Theory on Progressive Education by John Dewey that education must prepare students for active participation in a democratic, global society. Thus, the focus is on raising critical thinkers and inquirers who are active rather than passive learners. The teacher's job is to nurture and support children's innate curiosity and desire to learn, fostering internal motivation rather than reliance on external rewards. Strong emphasis of the theory is on problem solving and critical thinking; group work and development of social skills; understanding and action as the goals of learning; collaborative and cooperative learning projects. Emphasis is also given on lifelong learning, experiential learning; social skills and education for social responsibility and democracy.

Since there is a scanty of studies on leadership among young children, most specifically in the local setting, this research may serve as a groundwork for the activities that can be performed inside and outside the school to develop the leadership qualities of young children and to improve the delivery of quality education. It is hoped that this study will aid in enhancing the teaching and learning process leading to the development of $21^{\text {st }}$ century learners who possess leadership skills that would enable them to be adaptive, collaborative, globally competitive, and geared towards building a sustainable society.

\section{Literature Review}

Researchers have agreed that early-childhood education is a prime setting to study emerging social skills and leadership traits to explore ways to help young children gain the social and emotional competence necessary for lifelong success. It is believed that social and emotional readiness as expressed through positive and successful leadership skills can be taught most effectively when children are very young.

Leadership skills can be taught and instruction should begin in the early years (Abdigapbarova et al., 2016; Evans,2014; Ferland, et al, 2014; Zembat, 2017) and teachers are the most important actors that can create these opportunities ( Barnard, 2015; Dempster et al in Fox, 2012; Rodd, 2013). Children of all ages can take leadership roles (Miller et al., 2013;Montgomery \& Kehoe, 2015). Teachers should show the ability to form strong relationships in order to instill leadership skills in learners (Mulovhedzi \& Mudzielwana, 2016) and know how to support and nurture these leadership skills (Kasanoff, 2015;Rosenthal, 2012) because the path to leadership among young learners is in their teachers' hands at school (Barnard, 2015; Bradberry, 2015).

Investigation of leadership qualities in students according to teachers' opinions (Fox, 2015; and the ways of improving these qualities inside and outside the school was believed to contribute to the literature (Bailey, 2017; Wang et al, 2012). The most important leadership qualities that should be brought to students 
according to the teachers' opinions, are communication skills (Cansoy, 2017; Parlar, 2017), problem-solving skills (Cansoy,2017; Keskes, 2014), responsibility (Northouse, 2015), honesty, and cooperative learning (Karagianni \& Montgomery (2018)), respectively. Healthy social and interpersonal characteristics (Boas et al., 2014; Epstein, 2014) are also necessary in order to lead.

Activities for developing leadership qualities of students are increasingly gaining more importance in the solution of the problems related to education (Hay, I., \& Dempster, N., 2004; Şad and Şahiner, 2016). Leadership skills can be cultivated through participating in team work teaching activities (Chen, 2019) and sports activities (Cansoy, 2017; Foreman \& Retallick, 2012). Healthy self-concepts ( Boas et al,2014) are strong predictors of future achievement and healthy emotional adjustment, and social and interpersonal characteristics are necessary in order to lead (Epstein, 2014).

While there are numerous and abundant articles and literatures on leadership, not much research has been conducted on leadership among preschool children. Much of the research regarding leadership is focused on or structured around business leaders or executives. In educational setting, studies on leadership circled around the principals, school heads and administrators' leadership styles. More specifically, not much literature is available on leadership among Filipino preschool children.

In addition, literature showed that leadership development programs are necessary to create leadership opportunities for the young children and the teachers are the key factors in promoting and enhancing the skills.

\section{Method}

\section{Research Design}

This study made use of qualitative research design to identify the teachers' perception of a child leadership characteristics and to enumerate the best practices among teachers to develop child leaders.

\section{Respondents of the Study}

Using convenient sampling method, ten (10) private school teachers were purposively selected. Nine or ninety percent of the teachers who participated in are female, and 1 (10\% of them is male. The average age of the teachers is 33 years.

\section{Research Instrument}

Focus Group Discussion was employed for the data collection. Both pre-prepared questions and follow -up questions were asked in this approach. These questions focused on the teachers' identification of leadership qualities in young children. The teacher-participants were also asked to enumerate scenarios on how leadership skills could be developed. The participants shared best practices and suggested activities on how these leadership skills could be enhanced in a classroom setting.

\section{Data Collection Procedure}

During the Focus Group Discussion, the teacher-participants were asked on how they would describe leadership in young children. The teacher-participants were also asked to share best practices to develop and enhance child leadership. Experts' recommendations for analyzing qualitative data were considered (Miles \&Huberman, 1984). First, the researcher, read and reread the data. Next, she recorded all open-ended responses from the answers and made a table, listing all the descriptions. Then she looked for patterns and themes within the responses, highlighted similar themes for each answer, and made analytical notes. 
Texts and transcriptions in the data analysis is the exact conversation and based on the actual dialog of the teachers. The researcher categorized the participants' description of child leadership based on the list of descriptors of most prevalent child leadership characteristics collated from the different literatures (Cansoy, 2017; Foreman \& Retallick, 2012; Fox, 2015; Francis et al,2016; Northouse, 2015). Based on the answers of the FGD participants, the validation experts analyzed the data, checked the themes extracted from the codes, and evaluated and categorized the leadership descriptors. The top five (5) leadership descriptors that emerged are: (1) sought out by peers; (2) problem solver/carries out responsibilities; (3) empathetic/sensitive to feelings of others; (4) communicates well verbally; and (5) cooperative and collaborative.

\section{Ethical Consideration}

Ethical guidelines were followed for the whole research period. The researcher submitted the study for review and approval of the Ethics Review Board of the university. It followed the National Ethical Guidelines for Health and Health-Related Research 2017 prepared by the Philippine Health Research Ethics Board.

\section{Result and Discussion}

\section{Teachers' Descriptions of Child Leadership}

During the Focus Group Discussion, the Early Childhood Education teachers provided descriptions on how they perceive child leadership. Scenarios on how these characteristics are manifested were cited, supporting the description on child leadership. Also, best practices on enhancing the child leadership characteristics were shared.

The concepts of credibility and transferability are used instead of internal and external validity, and the concepts of consistency and verifiability are used instead of internal and external reliability in qualitative studies (Lincoln \& Guba, 1985). The researcher used direct quotations in accordance with the nature of the data to ensure transferability. To ensure consistency, external researchers who were expert in the field were consulted for verifiability. The experts analyzed the data, checked the themes extracted from the codes, and evaluated and confirmed leadership descriptors. The written data for content analysis was prepared by transcribing them from audio into text form and was divided into coding units guided by the qualitative questions of the study. A reading and re-reading of the FGD transcripts were done to identify the themes and their interconnection (Oliveira, 2016). The answers of the ten (10) participants were coded and categorized. Patterns and themes were then listed, and the final themes were considered based on the available literature on the most prevalent child leadership characteristics. Of the list of the child leadership characteristics, the top five (5) major themes that emerged are: (1) sought out by peers; (2) problem solver/carries out responsibilities; (3) empathetic/sensitive to feelings of others; (4) communicates well verbally; and (5) cooperative and collaborative.

\section{Theme 1: Sought out by peers/ delegates tasks}

Some of the leadership characteristics under the descriptor sought out by peers are: can be a model of appropriate behavior or skills for other children; is friendly and well-liked by others; can influence his/her classmates to do the tasks well; is trusted and followed by classmates; can take charge of a situation without being bossy.

The literature on the study conducted reveals that child leadership is a process by which one person influences the thoughts, attitudes and behaviors of other people (Mulovhedzi, 2016) which means that leadership is the ability to get other people to do something significant that they might not otherwise do. This is supported by the following statements:

T5: The other students trust the leader especially during groupwork activities. 
T1: A leader gives motivation like cheering other classmates who has difficulty coping with the lessons; He always says, "You can do it!".

T4: A child leader is always imitated by peers in the class even on the way he or she talks and do things.

T5: A child leader is always called by the teacher to assist him to collect papers of the class, to distribute school materials, and so on.

T7: A leader works with others well, and influences others to complete a task

\section{Theme 2: Problem solver/ carries out responsibility}

This descriptor includes the following perceived characteristics: does assigned tasks well; can solve simple problems; can follow given instructions; is organized in school materials and activities; can make good decisions / choices.

Problem solving contributes to child's self-improvement by exploring his talents and make child satisfy his own needs (Yildirim, 2014). The child wants to be encouraged to participate fully in problem solving activities. Problem solving has a special place in preschool period as it is a skill that needs to be developed at young ages (Oğuz \& Köksal Akyol, 2015). Through problem solving skills, children learn to focus their thoughts on a subject, generate alternative solutions, conceptualize causation and foresee the results.

In addition, self-motivated children with leadership skills are able to attract other children with their ideas and thoughts (Abdigapbarova, 2016). Children, who have organizational skills, easily find their way around any game situation and are able to quickly make the right decision. The list of findings is supported by the following statements:

T4: A leader is disciplined/ has good classroom management like if the class is noisy, the leader makes effort to keep the class organized.

T2: A leader plans/ organizes tasks given step by step; not impulsive - during project making or performance -based activities, he/she checks the materials to be used before starting with the project

T3: A leader can give solutions to specific tasks; like getting a tray so he can bring all the materials at once

T5: A child leader is punctual in doing the performance tasks; does work diligently and submits on time

T8: A leader makes decisions on his/her own without the influence of others

\section{Theme 3: Emphatic/ sensitive to feelings of others}

Shared inner perception is a pivotal interpersonal value a leader must possess (Yacat, 2013). It is described as involving tentative, exploratory and improvisatory behavior intended to avoid offending or hurting other people. It requires that a person actively senses or feels out the situation and the other person in a social interaction, and carefully come up with an appropriate behavior.

T7: A child leader manifests both cognitive and affective skills - the intelligence and emotional aspects. He is not only smart but what is important is that he also has concern for others.

T4: A child leader is sensitive to the feelings of others, he assists his classmates who has a hard time in class.

T5: A child leader gets along well with others and not choosy of his group mates or seat mate.

T2: A child leader sees his classmates as his equal, and he is not proud nor boastful.

T6: A child leader is respectful and is not offensive of others. 
Theme 4: Communicates well/ shows confidence.

The leadership qualities listed under this descriptor are: can express self and has good communication skills; displays confidence when telling messages/answering questions; is interactive and participative; can relay instructions to his/her classmates and can voice out without fear to the teacher the situation in class.

Communication and interpersonal skills are referred to as an art because a leader should be able to adjust to different personalities, know how to bring out the best in people and advance their growth, and be able to deliver more than what is required given limited resources. It is worth noting, that Filipinos really value a smooth-interpersonal relationship whether in a formal or informal group (Labor, 2017). Student leaders are comfortable communicating with people within their social groups. Filipino values such as shame have been reframed: from shame to external propriety. Good communication skills, such as one's capacity to listen, are perceived as a necessity as this "allows and facilitates communication with the followers."

T5: A leader has good communication and reasoning skills

T6: He/ she gives valuable suggestions in group work activities like what game to play or what toy to play with

T1: A leader is confident and can express ideas in class confidently

T2: A child leader speaks what is on his mind; he is not hesitant to voice what he wants and what he does not want.

T9: A child leader is a good listener, and not dominant to be always listened to.

T10: A child leader has the ability to make choices and relay the idea to others

The development of leadership skill is related to the development of communication skills. It is considered that effective communication improves listening and comprehension skills of the child and when it is integrated with empathy, problem solving, conflict management skills, it facilitates the leadership skill of the child (Kiersch \& Peters, 2017). Learning environments to support "ethical, transparent and reliable leadership skills" which are free from the business world are needed for the child to discover himself and explore his leadership potential.

\section{Theme 5: Collaborative and cooperative}

Collaborative and cooperative emerged as a theme in the leadership descriptors in this study. The teachers explained that leadership is the ability of the individual to conform with their classmates and groupmates. It is revealed that the respondents preferred a leader who is person-focused and group-centered, but also knowledgeable (Ilac, 2014). Respondents want a leader who is easy to talk to, listens with understanding and compassion, and cares about the others' welfare. If the leader is person-focused, the group members are more likely to feel more affection and warmth toward this leader. The leader is then able to bring people to work together as a team and get more positive results for the group.

To lead successfully in the Filipino context, a leader must be able to get along well with others without being controlling or abusive. Leaders are also able to connect with their members when they collaborate to accomplish important projects (Cimene, 2013). These literatures are supported by the following statements:

T5: A leader shows initiative and volunteers to do something like helping the teacher or helping a classmate

T10: A leader is responsive to different situations in the classroom; does not hesitate to do a task situations

T2: A leader can work well alone or with other students and can adapt well to different

T5: A child leader cooperates well during activities like group singing, project making, cleaning/fixing

T7: A child leader readily assists his classmates even if he is not task to do so. 


\section{Suggested Classroom Activities to Enhance Child Leadership}

Positive and engaging learning environments to support ethical, transparent, and reliable leadership skills which are free from the business world are needed for the child to discover himself and explore his leadership potentials. Based on the teachers' responses in the focus group discussion, they agreed that leadership skills could be enhanced in the classroom.

The following quotes emerged during the discussion:

T5: Children can lead the class in the prayer and in in the singing of the National Anthem.

T8: Children can guide the classmates in going to the comfort room.

T1: Children can arrange the books on the shelves.

T4: Children can be asked to report attendance within the row or small group.

T7: Assign them to check if the room is clean, if they could see pieces of paper scattered on the floor; if the chairs are properly arranged; if the materials on the shelves are in the right boxes, etc.

Leadership development could also be done through various strategies. It includes coaching, modeling, praising, direct teaching, or asking questions (Rodd, 2013). These are supported by the teachers' responses:

T6: I assign them to do simple tasks in the class.

T1: I keep on asking questions until they form ideas, and eventually they were the once formulating their own questions.

T7: I give scenarios where learners need to resolve issues to develop critical thinking skills.

T10: Praising the children when they accomplished even small tasks like finishing a written work, throwing of trash in the trash can, helping someone

T1: Giving of positive reinforcement is very effective like stamps, small gifts, prizes...

Methodology and techniques that teachers can use in the preschool period includes the game learning, drama method, field trip, and research, project, peer-teaching, analogy, concept map, case study, brainstorming, storytelling, station, talking pictures (Gentle-Gibbs, 2016). Most likely, educators are hoping that students will learn leadership skills through participating in classroom or school-wide character education programs (Parlar, 2017). The pedagogical foundation for teaching character skills would be under the label of social and emotional learning. Social and emotional learning incorporates building behavioral traits that a student will use both during school and at home (Andersen, 2011; Barthold, 2014; Parlar,2017). These findings are supported by the following statements:

T4: Child leaders are assigned to assist their classmates during group work activities.

T6: I let the slow readers sit beside the fast readers, or I assign a fast learner in each group for the members to emulate.

T9: I find peer tutoring as an effective tool and beneficial on both the tutor and the tutee. Their confidence level is both boost up; the tutor develops his leadership skills while the tutee becomes confident in the things he already knows from the peer tutoring sessions.

T2: In games and contests, child leaders are being emulated. It is easy to identify who has resourcefulness and leadership abilities.

T5: During games/activities, I allow the reserved or the shy ones to join the group of the active ones.

Problem-solving abilities, motivation, and thinking skills should be infused into leadership programs for students. Effective leadership development for students should increase the students' abilities to become aware of their own strengths, positive qualities of leaders, and global issues (Adams-Green, 2016).

T7: During the performance tasks or project making, when the active pupils perform, the shy ones would eventually follow, and so the discovery of the talents begin.

T5: During class and school programs, I allow everyone to participate and join and be given a 
part even for the smallest tasks. I let them contribute even if it's just by helping make material like trees or flowers. I also let them wear costumes and be part of the group.

T4: There are workbook activities about leadership that are very effective in instilling leadership lessons. I make sure to highlight the qualities of leaders in the workbook.

Storytelling dramas provide teachers with an easy-to-implement teaching strategy that builds community and aligns with current early childhood education quality standards and child development theory. The development of leadership skills is related to the development of communication skills (Kiersch \& Peters, 2017). It is considered that effective communication improves the listening and comprehension skills of the child and when it is integrated with empathy, problem-solving, conflict management skills, it facilitates the leadership skill of the child.

T9: I regularly tell stories, and ask my class "what will you do if...?" for valuing purposes

T3:I let the class analyze pictures/ scenarios from storybooks and relate them to real-life situations.

T1: Talent shows also showcase hidden talents and skills, so it is not purely academic. There are timid children who manifest abilities in singing or in playing instruments.

T8: I let them tell stories about known personalities and Bible characters for the children to emulate.

T10: I ask the class to relate their favorite book characters and enumerate the positive characteristics of these book characters they like to emulate

Cooperative learning, which is the instructional use of small groups in order for students to work together and make the best of each student's learning, is also an effective way to develop leadership skills (Montgomery, 2015). This also includes the methods of competitive team activities, story-telling and questioning, story building up and enacting and experiences sharing.

\section{Conclusion}

Related literatures aided in the conclusion that while there are numerous and abundant articles and literatures on leadership, not much research has been conducted on leadership among preschool children.

Early childhood education teachers have varied perception on child leadership. It is concluded that there is a need to realize how important it is to teach and encourage young learners' emerging leadership skills so that young learners will continue practicing them and noticing them. As the domains overlap, one characteristic may be representative of more than one domain. Educators who recognize child leadership characteristics from multiple domains will be more effective at nurturing children's leadership behaviors. Therefore, teachers must be made aware that they have a strong influence on young learners and that the activities presented in the classroom played a big part in the enhancement of the children's leadership skills. Learners should be regularly encouraged to build their leadership skills so that they can assert themselves in school and also outside in the world.

The researcher confirmed that additional research is needed in the area of child leadership to help teachers increase their awareness of child leadership and to help them identify leadership potential in young children. Conversely, if teachers recognize child leadership, they can support and encourage these behaviors in children. Indeed, researches on leadership among young children in Philippine setting is needed to fill the gap in the literature and to encourage building a positive teaching-learning process.

\section{Recommendations}

The Department of Education together with the curriculum planners and policy-makers may refer to the findings of this study in formulating policies for holistic, positive and transformational learning environments. The following recommendations are presented with the hope of improving the quality of learning for a 
sustainable future:

1. Develop training manuals and teacher-training programs that motivate teachers how important it is to teach, encourage and support learners to develop leadership skills at an early stage.

2. Conduct conceptual and applied training and seminars of teachers on how to enhance and develop learners' leadership skills.

3. Provide teachers with listings of suggested actual activities to enhance leadership skills among young children

4. Conduct additional research studies on teachers' training and recognition and support of learners' leadership.

\section{Acknowledgements}

The researcher would like to thank the teacher-participants for their contribution for the success of this study.

\section{References}

Abdigapbarova, U. M. et al (2016). Communication Through Dialogue Between Preschool Children with Leadership Skills. IEJME- Mathematics Education, 11 (5), 1343-1350

Adams-Green, S.D. (2016). Teacher Perceptions of Leadership Potential of Gifted and Talented Students. Morgan State University.

Andersen, L. (2011). The effects of formal leadership-lessons on the emergence of positive socialleadership skills of pre-kindergarten students. The School of Education. St. John's University. New York

Bailey, D. et al (2017). Identifying and Living Leadership in the Lives of Prekindergarten Through \$th- grade Girls. Journal of Research in Childhood Education, Volume 31, 2017- Issue 4 published online, 19 Sep 2017.

Barnard J. (2015). Teachers Who Lead The Way. From <http://www.teacher-Who-lead-the-way> (Retrieved on 30 August 2018).

Barthold, S.K. (2014). "The Emergence of Leadership in Children: The Role of Play, Athletics, and School" CMC Senior Theses. Paper 859.http://scholarship.claremont.edu/cmc_theses/859

Boas, S., House, R. \& Arthur, M. (2014). The motivational effects of charismatic leadership: A self-concept base theory. Organizational Science, 4(4),577-59

Bradberry, T. (2015). Powerful Ways to Mold Your Children into Leaders. California: Forbes Contributor

Cansoy, R. (2017). The Effectiveness of Leadership Skills Development Program for University Students. Journal of History Culture and Art Research, 6(3), 65-87. doi:http://dx.doi.org/10.7596/taksad.v6i3.899

Chen, W. (2019). A Case Study on Developing Students' Leadership Skills via Team Work Activities. Department of Humanities, Shanghai Art \& Design Academy, Shanghai, China, Open Journal of Social Sciences. Vol. 7. No. 10. October 2019 D

Cimene, F. T. A., \& Aladano, A. N. (2013). Leadership Perspective from the Philippines: Its Implications for Theory, Research and Practice. Culture and Gender in Leadership, 48-63.

Dempster, N., Stevens, E., \& Keeffe, M. (2011). Student and youth lleadership : $\quad$ A focused literature review. Leading and Managing,

Epstein, A. S., (2014). The intentional teacher: Choosing the best strategies for young children's 
learning. Washington, DC: NAEYC.

Evans, S. (2014). Making leaders: examining how elementary school students develop an understanding of leadership and show emerging leadership tendencies. Virginia Commonwealth University.

Ferland, A., et al. (2014) Leadership skills are associated with health behaviours among Canadian children. Health Promotion International, 30(1), 76-88.

Foreman \& Retallick, (2012). Using Involvement Theory to Examine the Relationship between Undergraduate Participation in Extracurricular Activities and Leadership Development. Iowa State University.

Fox, D., Flynn, L. \& Austin, P. (2015) Child Leadership: Teachers' Perceptions and Influences. Childhood Education, 91(3), 163-168.

Francis, G., Blue-Banning, M., Haines, S. \& Gross, J. (2016) School culture in inclusive schools: Parental perspectives on trusting family partnerships. Education and Training for Autism and Developmental Disabilities.

Gentles-Gibbs, N. (2016) Leadership Development. Families in society: the journal of contemporary human services, 97(2), 95-101.

Hay, I., \& Dempster, N. (2004). Student leadership development through general classroom activities. Educating: Weaving Research into Practice: Volume 2, 141

Ilac, E. J. (2014). What Makes a Filipino leader? first published in the Business Section of the $\begin{array}{lllll}\text { Philippine Daily } & \text { Inquirer } & \text { 2011) }\end{array}$ http://business.inquirer.net/money/topstories/view/20110130317556/What-makes-a-Filipino-leader

Karagianni, D. \& Montgomery, J. (2018) Developing leadership skills among adolescents and young adults: a review of leadership programmes, International Journal of Adolescence and Youth, 23:1, 86-98, DOI: 10.1080/02673843.2017.129292

Kasanoff B. (2015). Steps to Helping Your Child Become a Leader: Leadership Development. LEAP Africa. From http://www.5steps.childleader/pdf (Retrieved on 29 July 2018)

Keskes I. (2014). Relationship between leadership style and dimensions of employee organizational commitment: A critical review and discussion of future directions. Intangible Capital, 10(1): 26-51.

Kiersch, C. and Peters, J. (2017). Leadership from the Inside Out: Student Leadership Development within Authentic Leadership and Servant Leadership Frameworks. Journal of Leadership Education, 16(1), 148-168.

Labor, J. SJ. (2017). Filipino Student Council Heads' Leadership Frames: A Phenomenographic Inquiry. College of Mass Communication, University of the Philippines Colegio de San Juan de Letran-Manila, Philippines. The Journal of Student Leadership • Volume 1 Issue 1 . $2017 \cdot 25-35$

Lincoln, YS. \& Guba, EG. (1985). Naturalistic Inquiry. Newbury Park, CA: Sage Publications

Miles and Huberman. (1984). Qualitative Data Analysis: A sourcebook of new methods. Sage Publications.

Montgomery, A., \& Kehoe, I. (Eds.). (2015). Reimagining the purpose of schools and educational organizations: Developing critical thinking, agency, beliefs in schools and educational organizations. Cham, Switzerland: Springer.

Mulovhedzi, S.A. \& Mudzielwana, N.P. (2016). Importance of Teaching Leadership Skills in the Foundation Phase. Department of Early Childhood Education, School of Education, University of Venda, Thohoyandou, Republic of South Africa

Northouse, P. G. (2015). Leadership: Theory and practice. Thousand Oaks, CA: Sage Publications. 
Oğuz, V. and Köksal Akyol, A. (2014). A Study on Problem Solving Skills of Children Attending Nursery School. International Journal of Social Sciences

Oliveira, K. (2016). Children's Implicit Leadership Theories in Middle Childhood: Christian Children's Perceptions in the Cavite Province, Journal of Research on Christian Education, $25: 3,251-272$

Parlar, H. et al (2017). Leadership Development in Students: TeaOpinions Regarding Activities that can be Performed at Schools. Universal Journal of Educational Research 5(2): 217-227, 2017 http://www.hrpub.org DOI: 10.13189/ujer.2017.050207

Rodd J. (2013). Leadership in Early Childhood: The Pathway to Professionalism. Australia and New Zealand: McGraw-Hill, Open University Press.

Rosenthal, S. A. (2012). National Leadership Index 2012: A national study of confidence in leadership. Cambridge, MA: Harvard Kennedy School, Harvard University.

Şad, S. N., \& Şahiner, Y. K. (2016). Student, Teacher, and Parents' Opinions on the Transition from Primary to Secondary Education (TEOG) System. lköğretim Online, 15(1).

Wang, B. et al (2012). An investigation and analysis of high school student leadership in Central China. International Journal Of Psychology, 47, 1-2.

Yacat, J. (2013). Filipino psychology (Sikolohiyang Pilipino). In K. D. Keith (Ed.), The Encyclopedia of Cross-Cultural Psychology (pp. 551-556). Hoboken, NJ: Wiley-Blackwell

Yildirim, C. (2014). "Exploring the dimensions of nomophobia: Developing and validating a questionnaire using mixed methods research". Graduate Theses and Dissertations. 14005 